\title{
KINERJA ORGANISASI PUBLIK DALAM MENCAPAI TARGET SASARAN
}

\author{
Laili Salamatul Khoiriyah dan Muammar Alkadafi \\ FEKONSOS Universitas Islam Negeri Sultan Syarif Kasim, Jl. H.R Soebrantas, Pekanbaru
}

\begin{abstract}
This research was conducted at the Department of Manpower and Transmigration of Riau Province. The purpose of this research is to analyze the performance of public organizations at the Department of Manpower and Transmigration of Riau Province and to find out the obstacles experienced in achieving the target performance. This performance appraisal refers to the theory of Agus Dwiyanto.The method used is a qualitative descriptive method. The data collection techniques used in this study were observation, interviews, and documentation. The research informants were carried out by using purposive sampling technique. The results of the analysis of this study are the performance of the Riau Province Manpower and Transmigration Office is said to be good, This is evidenced by the decline in the open unemployment rate and the existence of transmigration communities who are no longer being fostered. In responding to complaints from workers and the community, the Dinas tries to respond quickly according to work procedures in resolving complaint cases and makes considerations before following up on complaints from the transmigration community. The agency has conducted training, apprenticeship and job fair programs to reduce the open unemployment rate. With the community's satisfaction with the tasks carried out, this Dinas has been responsible and consistent with its duties to fulfill the will of the community. The obstacles experienced by this agency are team factors / co-workers, system factors, and situation factors.
\end{abstract}

\begin{abstract}
Abstrak: Penelitian ini dilaksanakan pada Dinas Tenaga Kerja dan Transmigrasi Provinsi Riau. Tujuan penelitian ini adalah untuk menganalisa kinerja organisasi publik pada Dinas Tenaga Kerja dan Transmigrasi Provinsi Riau dan untuk mengetahui hambatan yang dialami dalam mencapai target sasaran kinerjanya. Penilaian kinerja ini mengacu pada teori Agus Dwiyanto. Metode yang digunakan adalah metode deskriptif kualitatif. Teknik pengumpulan data yang digunakan dalam penelitian ini yaitu observasi, wawancara, dan dokumentasi. Informan penelitian dilakukan dengan teknik purposive sampling. Hasil analisis dari penelitian ini yaitu Kinerja Dinas Tenaga Kerja dan Transmigrasi Provinsi Riau dikatakan baik, dibuktikan dengan menurunnya tingkat pengangguran terbuka dan adanya masyarakat transmigrasi yang tidak dibina lagi. Dalam menanggapi keluhan tenaga kerja dan masyarakat, Dinas berusaha merespon dengan cepat sesuai dengan prosedur kerja dalam penyelesaian kasus pengaduan dan melakukan pertimbangan terlebih dahulu sebelum bertindak memenuhi keluhan dari masyarakat transmigrasi. Dinas sudah melakukan program pelatihan, pemagangan, dan job fair untuk menurunkan tingkat pengangguran terbuka. Dengan adanya kepuasan masyarakat terhadap tugas yang dilaksanakan, Dinas ini telah bertanggung jawab dan konsisten atas tugasnya untuk memenuhi kehendak masyarakat. Hambatan yang dialami oleh instansi ini seperti faktor team/rekan kerja, faktor sistem, dan faktor situasi.
\end{abstract}

Kata kunci: kinerja, organisasi publik, kepuasan masyarakat, tim kerja

\section{PENDAHULUAN}

Organisasi atau instansi dalam melaksanakan kinerja selalu diarahkan untuk mencapai tujuannya. Tujuan adalah sesuatu yang diharapkan organisasi untuk dicapai. Pencapaian tujuan organisasi menunjukkan sebagai kinerja atau performa organisasi. Hasil kerja organisasi diperoleh dari serangkaian aktivitas yang dijalankan organisasi. Aktivitas organisasi dapat berupa pengelolaan sumber daya organisasi maupun proses pelaksanaan kerja yang diperlukan untuk mencapai tujuan organisasi (Wibowo, 2010).

Kinerja pada dasarnya adalah apa yang dilakukan atau tidak dilakukan pegawai. Kinerja adalah hasil kerja yang dicapai oleh seseorang atau sekelompok orang dalam suatu organisasi sesuai dengan wewenang dan tanggung jawab masing-masing dalam rangka mencapai tujuan organisasi yang bersangkutan secara legal, tidak melanggar hukum dan sesuai dengan moral dan etika (Nawawi, 2010).

Pengukuran kinerja merupakan suatu proses penilaian kemajuan pekerjaan terhadap pencapaian tujuan dan sasaran yang telah ditentukan termasuk informasi atas efisiensi penggunaan sumber daya dalam menghasilkan barang dan jasa, kualitas barang dan jasa, perbandingan hasil kegiatan dengan target, dan efektivitas 
tindakan dalam mencapai tujuan. Pengukuran bertujuan untuk mengetahui apakah hasil kerja dari pegawai sudah memenuhi standar kerja yang diharapkan atau belum. Kinerja dalam organisasi merupakan jawaban dari berhasil atau tidaknya tujuan organisasi yang telah ditetapkan.

Dinas Tenaga Kerja dan Transmigrasi Provinsi Riau sebagai unsur otonomi daerah dibidang tenaga kerja dan transmigrasi yang dibentuk dengan Peraturan Daerah Provinsi Riau No. 4 Tahun 2016 Tentang Pembentukan Dan Susunan Perangkat Daerah Provinsi Riau. Untuk melaksanakan tugasnya, Dinas Tenaga Kerja dan Transmigrasi Provinsi Riau mempunyai fungsi perumusan kebijakan teknis di bidang tenaga kerja dan transmigrasi penyelenggaraan urusan pemerintahan dan pelayanan umum di bidang tenaga kerja dan transmigrasi lingkup Provinsi, pembinaan dan pelaksanaan tugas di lingkup Provinsi, pemantauan, evaluasi dan pelaporan bidang tenaga kerja dan transmigrasi lingkup Provinsi, pelaksanaan tugas kesekretariatan Dinas, pelaksanaan tugas lain di bidang tenaga kerja dan transmigrasi yang diserahkan oleh Gubernur sesuai dengan tugas pokok dan fungsinya.

Tingkat pengangguran terbuka di Riau menurun secara tidak stabil dimana pada tahun 2005 sampai tahun 2012 tingkat pengangguran terbuka menurun dari $12,2 \%$ menjadi $4,3 \%$, terlihat berkurang 7,9\%. Tetapi pada tahun 2013 sampai tahun 2015 terjadi peningkatan kembali hingga 7,83\%. Kemudian tingkat pengangguran terbuka mulai menurun lagi pada tahun 2016, 2017, dan 2018. Tetapi pada tiga tahun terakhir, tingkat pengangguran terbuka hanya menurun sedikit demi sedikit. Jumlah penduduk usia kerja pada tahun 2018 terjadi peningkatan yaitu dari 4.634.041 penduduk menjadi 4.765.436 penduduk. Pada tabel ini juga dapat dilihat bahwa terjadinya penurunan bukan angkatan kerja dari 1.668.456 penduduk menjadi 1.657 .038 penduduk, tetapi angka pengangguran terbuka terjadi peningkatan dari 184.564 penduduk menjadi 192.801 penduduk.

Fenomena yang ditemukan pada Dinas Tenaga Kerja dan Transmigrasi Provinsi Riau, yaitu masih terdapat hambatan yang dialami dan perlu diatasi agar kinerja instansi dalam me- nurunkan tingkat pengangguran terbuka dan meningkatkan kemandirian masyarakat transmigrasi dapat lebih ditingkatkan lagi. Berdasarkan penilaian yang penulis dapat di LKjIP yang dibuat oleh Dinas Tenaga Kerja dan Transmigrasi Provinsi Riau masih ada target sasaran kerja yang belum terrealisasi sepenuhnya

Tingkat Pengangguran Terbuka/TPT, Tingkat Partisipasi Agkatan Kerja/TPAK, dan Persentase Transmigrasi Mandiri yang ditargetkan oleh Dinas Tenaga Kerja dan Transmigrasi Provinsi Riau masih ada yang belum mencapai $100 \%$. Oleh karena itu, dalam situasi seperti ini Kepala Dinas maupun Kepala Bidang perlu melakukan pengukuran kinerja untuk meninjau kembali sejauh mana keberhasilan organisasinya dan mengevaluasi kekurangan-kekurangan yang terdapat didalamnya sehingga dapat diambil tindakan secepatnya untuk mengatasi masalah tersebut. Pada tahun 2018 misalnya, realisasi indikator kinerja Tingkat Pengangguran adalah 6,20\% dengan capaian kinerja sebesar 107,74\%. Realisasi target ini melebihi target yang ditentukan yaitu $6,68 \%$, dimana indikator menurunkan tingkat pengangguran terbuka ini berarti semakin kecil angka realisasi maka akan semakin tinggi kinerja.

Pada Indikator Tingkat Partisipasi Angkatan Kerja (TPAK), sasaran ini ter-realisasi dengan capaian kinerja sebesar 102,45\%. Definisi Tingkat Partisipasi Angkatan Kerja (TPAK) adalah Penduduk yang termasuk bukan angkatan kerja adalah penduduk usia kerja (15 tahun dan lebih) yang masih sekolah, mengurus rumah tangga atau melaksanakan kegiatan lainnya selain kegiatan pribadi. Semakin tinggi TPAK menunjukkan bahwa semakin tinggi pula pasokan tenaga kerja (labour supply) yang tersedia untuk memproduksi barang dan jasa dalam suatu perekonomian.

Pencapaian kinerja Program Transmigrasi Lokal adalah terlaksananya kegiatan Pembinaan transmigrasi lokal yang menciptakan kemandirian warga trasmigrasi. Bidang Ketransmigrasian membina sebanyak 6Unit Pemukiman Transmigrasi (UPT) yang tesebar di $4 \mathrm{Kab} / \mathrm{Kota}$, namun target sasaran dalam meningkatkan kemandirian warga transmigrasi hanya tercapai sebesar 
$79,14 \%$. Maka, terdapat 20,86\% warga transmigrasi yang belum mandiri, sehingga warga tersebut masih mendapatkan bantuan berupa jaminan hidup dari pemerintah.

\section{METODE}

Penelitian ini dilaksanakan di Kantor Dinas Tenaga Kerja dan Transmigrasi Provinsi Riau. Jenis penelitian dalam penelitian ini adalah deskriptif kualitatif. Sumber data primer diperoleh melalui observasi (pengamatan langsung pada objek penelitian), wawancara mendalam (indepht interview) dengan para narasumber/ informan yang dipilih menggunakan teknik purposive sampling, dan dokumentasi. Data sekunder diperoleh dari data-data yang sudah tersimpan pada objek penelitian yang berhubungan dengan program dan kegiatan kerja. Data yang sudah diperoleh dalam penelitian dikumpulkan, selanjutnya dikelompokkan untuk dijadikan bahan masukan sebagai bahan bukti dalam pelaksanaan penulisan ilmiah. Selanjutnya dilaksanakan konfirmasi terhadap informan lainnya untuk memperoleh data yang valid. Setelah data tersebut diolah, selanjutnya dilakukan pembahasan terhadap data yang bersifat kualitatif dalam bentuk deskriptif dengan menganalisa secara seksama.

Informasi yang didapatkan disajikan dalam bentuk teks dengan sebaik mungkin, tanpa adanya penambahan dari fakta yang ada. Hal tersebut bertujuan untuk dapat menyajikan data dengan tepat dan benar sesuai keadaan yang sebenarnya di lapangan. Selanjutnya analisis data dilakukan secara induktif, yaitu penganalisaan dengan cara menarik kesimpulan atas data yang berhasil dikumpulkan dari bentuk umum atau penalaran untuk mencapai kesimpulan mengenai semua unsur-unsur penelitian yang tidak diperiksa/diteliti dalam penelitian.

\section{HASIL DAN PEMBAHASAN Kinerja Organisasi Publik Produktivitas}

Pada indikator produktivitas kinerja organisasi publik menurut Dwiyanto (2010) ini terdapat beberapa sub-indikator, yaitu kualitas pelayanan, efisiensi, dan penjadwalan. Dalam
Peraturan Pemerintah Republik Indonesia Nomor 96 Tahun 2012 tentang Pelaksanaan UndangUndang Nomor 25 Tahun 2009 Tentang Pelayanan Publik Pasal 1 mengatakan bahwa Pelayanan Publik adalah kegiatan atau rangkaian kegiatan dalam rangka pemenuhan kebutuhan pelayanan sesuai dengan peraturan perundangundangan bagi setiap warga negara dan penduduk atas barang, jasa, dan/atau pelayanan administratif yang disediakan oleh penyelenggara pelayanan publik.

Menurut Zauhar (2005), kualitas pelayanan adalah penyesuaian terhadap perincianperincian (conformance to specification) dimana kualitas ini dipandang sebagai derajat keunggulan yang ingin dicapai, dilakukannya kontrol terus menerus dalam mencapai keunggulan tersebut dalam rangka memenuhi kebutuhan pengguna jasa. Pelayanan merupakan respon terhadap kebutuhan manajerial yang hanya terpenuhi jika pengguna jasa itu mendapatkan produk yang mereka inginkan. Berkualitas mempunyai arti memuaskan kepada yang dilayani, baik internal maupun eksternal dalam arti optimal pemenuhan atas tuntutan masyarakat.

Penjadwalan adalah aktivitas perencanaan untuk menentukan kapan dan dimana setiap kegiatan sebagai bagian dari pekerjaan secara keseluruhan harus dilakukan pada sumber daya yang terbatas, serta pengalokasian sumber daya pada suatu waktu tertentu dengan memperhatikan kapasitas sumber daya yang ada. Penjadwalan dapat diartikan sebagai pengalokasian sejumlah sumber daya (resource) untuk melakukan sejumlah tugas atau operasi dalam jangka waktu tertentu dan merupakan proses pengambilan keputusan yang peranannya sangat penting dalam industri manufaktur dan jasa yaitu mengalokasikan sumber-sumber daya yang ada agar tujuan dan sasaran perusahaan lebih optimal (Baker \& Trietsch, 2009).

Efesiensi berhubungan erat dengan konsep produktifitas. Pengukuran efisiensi dilakukan dengan perbandingan antara output yang dihasilkan terhadap input yang digunakan (cost of output). Proses kegiatan operasional dapat dikatakan efesien apabila suatu produk atau hasil kerja tertentu dapat dicapai dengan penggunaan 
sumber daya dan dana yang serendah-rendahnya (spending well). Indikator efesiensi menggambarkan hubungan antara masukan sumber daya oleh suatu unit organisasi dan keluaran yang dihasilkan (Mardiasmo, 2009).

Ditinjau dari sub-indikator kualitas pelayanan, Dinas Tenaga Kerja dan Transmigrasi Provinsi Riau sudah menjalankan tugasnya sesuai dengan bidangnya masing-masing. Pada Bidang Pelatihan dan Penempatan Tenaga Kerja menjalankan tugasnya sesuai dengan tugas, pokok dan fungsi (TUPOKSI) masing-masing seksi. Seperti Seksi Pelatihan, Pemagangan, dan Produktivitas Tenaga Kerja, seksi ini melakukan pelatihan wirausaha, seperti pembuatan tas dari tali kur, pelatihan masak-memasak, pelatihan kecantikan dan lain sebagainya. Bidang Pelatihan dan Penempatan Tenaga Kerja ini memberikan pelayanan untuk meningkatkan jumlah tenaga kerja yang kompeten, produktif, dan berdaya saing sesuai dengar pasar kerja serta menciptakan wirausaha baru. Kalau program pemagangan yang dijalankan itu jurusannya seperti perhotelan, desain grafis, mekanik roda dua, mekanik roda empat, menjahit, dan lain sebagainya. Kemudian contoh pelatihan dari Seksi Penempatan dan Perluasan Kerja itu program padat karya seperti pemberian bibit-bibit ikan. Program padat karya ini bertujuan agar tersedianya kesempatan kerja atau usaha dalam bentuk kegiatan usaha ekonomi produktif pedesaan yang berkesinambungan bagi masyarakat setempat. Dan pada Seksi Infomasi Pasar Kerja itu menjalankan tugas nya dengan membuat program job fair untuk meminimalisir angka pengangguran.

Berdasarkan sasaran kinerja Dinas Tenaga Kerja dan Transmigrasi Provinsi Riau, yaitu mengurangi angka pengangguran belum banyak menurun, dengan menjalankan program jobfair, dapat dilihat pada tabel dibawah ini dimana hanya beberapa dari pencari kerja yang diterima. Kemudian dalam meningkatkan perluasan kesempatan kerja di sektor informal, dinas ini menjalankan program pelatihan wirausaha baru dan pelatihan kader teknologi padat karya sehingga banyak penduduk yang bisa berwirausaha melalui pelatihan yang diberikan. Pada meningkatkan kompetensi tenaga kerja serta penye- barluasan informasi ketenagakerjaan, dinas ini menjalankan program pemagangan dan pelatihan. Dengan program ini, dinas mampu meningkatkan kompetensi tenaga kerja sehingga tenaga kerja memiliki daya saing dan mampu berwirausaha melalui hasil yang didapatkan dari programini.

Tabel 1. Jumlah Pencari Kerja yang di Terima melalui Program Job Fair

\begin{tabular}{|c|c|c|c|c|c|}
\hline \multirow{2}{*}{ Tahun } & \multicolumn{5}{|c|}{ Jumlah } \\
\cline { 2 - 6 } & $\begin{array}{c}\text { Pencari } \\
\text { Kerja }\end{array}$ & Perusahaan & Lowongan & Jabatan & $\begin{array}{c}\text { Pencaker } \\
\text { Diterima }\end{array}$ \\
\hline 2016 & 6461 & 53 & 2713 & 200 & 254 \\
\hline 2017 & 7200 & 50 & 1826 & 125 & 390 \\
\hline 2019 & 3405 & 42 & 1422 & 180 & 91 \\
\hline
\end{tabular}

Ditinjau dari sub-indikator penjadwalan, Dinas Tenaga Kerja dan Transmigrasi Provinsi Riau menjalankan program-program seperti pelatihan dan pemagangan ini sudah sesuai dengan perjanjian yang sudah dijadwalkan, Dinas Tenaga Kerja dan Transmigrasi Provinsi Riau juga melakukan monitoring pada saat program itu berjalan minimal satu kali dalam pelaksanaan, dan setelah laporan dari program-program tersebut selesai kemudian di evaluasi oleh pihak pemerintah untuk dapat dimaksimalkan lagi pada pelaksanaan program-program tersebut pada tahun selanjutnya. Kemudian pada bidang ketransmigrasian, Dinas Tenaga Kerja dan Transmigrasi Provinsi Riau memantau apakah daerah transmigrasi sudah mandiri atau belum. bagaimana perkembangan masyarakat transmigrasi, apakah ada keluhan atau tidak. Dan untuk monitoring perbulan, instansi memberikan tugas tersebut kepada kepala UPT untuk dimintai laporan setiap bulannya tanpa harus pihak pemerintah provinsi yang turun ke daerah transmigrasi tersebut. Tetapi untuk lebih memaksimalkan lagi, pemerintah Provinsi tetap melakukan evaluasi dan mengontrol perkembangan masyarakat transmigrasi minimal dua atau tiga kali dalam setahun.

Ditinjau dari sub-indikator efisiensi, efisiensi anggaran biaya itu masih terdapat kekurangan, seperti program-program pemagangan ada yang dipangkas kelas nya atau dikurangi jurusannya. Kemudian untuk ketransmigrasian masih kurang terpenuhinya pembangunan fasilitas sarana dan prasarana di daerah transmigrasi sehingga mem- 
buat program dan proses pembangunan fasilitas menjadi sedikit terhambat. Dan untuk mengatasi masalah anggaran ini, Dinas Tenaga Kerja dan Transmigrasi Provinsi Riau hanya bisa menunggu dana dari APBD pertahunnya, sebab Provinsi Riau mendapatkan dana dari DBH (Dana Bagi Hasil), sehingga dana yang didapatkan tidak menentu seberapa besarnya. Tetapi dengan keterbatasan dana yang diterima, Dinas Tenaga Kerja dan Transmigrasi Provinsi Riau tetap mengupayakan bagaimana caranya agar programprogram tetap berjalan lancar sebagaimana mestinya sehingga visi dapat tercapai sesuai dengan renstra yang dibuat.

Berikut tabel yang menunjukkan realisasi anggaran dalam menjalankan program di Dinas Tenaga Kerja dan Transmigrasi Provinsi Riau.

Tabel 2. Realisasi Anggaran Program Dinas Tenaga Kerja dan Transmigrasi Provinsi Riau

\begin{tabular}{|c|c|c|c|c|}
\hline NO & PROGRAM & $\begin{array}{l}\text { ANGGARAN } \\
\text { TAHUN 2017 } \\
\text { (Rp.) } \\
\end{array}$ & $\begin{array}{l}\text { REALISASI } \\
\text { (Rp.) }\end{array}$ & $\begin{array}{c}\text { Capaian } \\
(\%)\end{array}$ \\
\hline 1. & $\begin{array}{l}\text { Program Pelayanan } \\
\text { Administrasi }\end{array}$ & 4.183 .202 .000 & 3.950 .322 .471 & 94.43 \\
\hline 2. & $\begin{array}{l}\text { Program } \\
\text { Peningkatan } \\
\text { Sarana dan } \\
\text { Prasarana Aparatur }\end{array}$ & 2.779 .280 .000 & 2.617 .628 .112 & 94.18 \\
\hline 3. & $\begin{array}{l}\text { Program } \\
\text { Peningkatan } \\
\text { Disiplin Aparatur }\end{array}$ & 179.750 .000 & 147.200 .00 & 81.89 \\
\hline 4. & $\begin{array}{l}\text { Program } \\
\text { Peningkatan } \\
\text { kapasitas Sumber } \\
\text { Daya Apatur }\end{array}$ & 144.500 .000 & 144.250 .00 & 99.83 \\
\hline 5. & $\begin{array}{l}\text { Program } \\
\text { peningkatan } \\
\text { Pengembangan } \\
\text { Sistem Pelaporan } \\
\text { capaian Kinerja } \\
\text { dan Keuangan }\end{array}$ & 455.365 .0000 & 450.556 .800 & 98.94 \\
\hline 6. & $\begin{array}{l}\text { Program } \\
\text { Peningkatan } \\
\text { Kualitas dan } \\
\text { Produktivitas } \\
\text { Tenaga Kerja }\end{array}$ & 12.197 .034 .000 & 11.280 .553 .077 & 92.49 \\
\hline 7. & $\begin{array}{l}\text { Program } \\
\text { Peningkatan } \\
\text { Kesempatan Kerja } \\
\text { dan Perluasan } \\
\text { kerja }\end{array}$ & 4.555 .513 .000 & 4.0112 .029 .605 & 88.07 \\
\hline 8. & $\begin{array}{l}\text { Program } \\
\text { perlindungan dan } \\
\text { Pengembangan } \\
\text { lembaga } \\
\text { Ketenagakerjaan }\end{array}$ & 2.139 .835 .000 & 1.944 .872 .244 & 90.89 \\
\hline 9. & $\begin{array}{l}\text { Program } \\
\text { Pengembangan } \\
\text { Wilayah } \\
\text { Transmigrasi }\end{array}$ & 1.201 .493 .000 & 1.057 .931 .900 & 88.05 \\
\hline 10. & $\begin{array}{l}\text { Prgram } \\
\text { Transmigrasi } \\
\text { Lokal } \\
\end{array}$ & 3.985 .007 .000 & 3.881 .759 .875 & 97.41 \\
\hline 11. & $\begin{array}{l}\text { Program } \\
\text { Pengembangan } \\
\text { Data dan Informasi }\end{array}$ & 75.000 .000 & 74.420 .000 & 99.23 \\
\hline & JUMLAH & 31.895.979.000 & 29.561.524.652 & 92.68 \\
\hline
\end{tabular}

Sumber: Disnakertrans Provinsi Riau, 2018
Berdasarkan dua tabel realisasi anggaran di atas, dapat dilihat bahwa anggaran yang diberikan untuk menjalankan program pada tahun 2017 dan tahun 2018 sudah dapat dikatakan efisien karena Dinas Tenaga Kerja dan Transmigrasi Provinsi Riau mampu menggunakan dana dengan serendah-rendahnya dan program serta kegiatan berjalan dengan efektif. Kemudian, pada tahun 2018 hanya 37,78\% anggaran yang terealisasikan, dimana masih 62,22\% anggaran tersisa. Berbeda dengan hasil wawancara yang penulis lakukan pada Dinas Tenaga Kerja dan Transmigrasi Provinsi Riau dimana para informan mengatakan bahwa terdapat kurangnya anggaran dan menghambat terjalannya program.

\section{Responsivitas}

Responsivitas adalah kemampuan organisasi untuk mengenali kebutuhan masyarakat, menyusun agenda dan prioritas pelayanan, serta mengembangkan program-program pelayanan public sesuai dengan kebutuhan masyarakat. dan aspirasi masyarakat. Responsivitas disini menunjuk pada keselarasan antara program dan kegiatan pelayanan dengan kebutuhan dan aspirasi masyarakat. Responsivitas secara langsung menggambarkan kemampuan organisasi public dalam menjalankan misi dan tujuannya, terutama untuk memenuhi kebutuhan masyarakat. Responsivitas yang rendah ditunjukkan dengan ketidakselarasan antara pelayanan dengan kebutuhan masyarakat (Dwiyanto, 2010).

Ditinjau dari indikator responsivitas, Dinas Tenaga Kerja dan Transmigrasi Provinsi Riau selalu berusaha untuk merespon dengan cepat tentunya sesuai dengan prosedur kerja yang telah diatur pada Undang-undang No. 2 Tahun 2004 tentang Perselisihan Hubungan Industrial dan untuk keluhan masyarakat transmigrasi tentunya Dinas Tenaga Kerja dan Transmigrasi Provinsi Riau melakukan pertimbangan terlebih dahulu sebelum memenuhi keluhan dari masyarakat tersebut. Berikut adalah prosedur penyelesaian Perselisihan Hubungan Industrial.

\section{Akuntabilitas}

Akuntabilitas yaitu menunjukkan seberapa besar kebijakan dan kegiatan birokrasi public 
tunduk pada pejabat politik yang dipilih oleh rakyat. Kinerja organisasi publik tidak hanya dilihat dari ukuran internal yang dikembangkan oleh organisasi public atau pemerintah, seperti pencapaian target. Kinerja sebaiknya juga harus dinilai dari ukuran eksternal, seperti kegiatan organisasi public itu konsisten dengan kehendak masyarakat banyak (Dwiyanto, 2010).

Ditinjau dari indikator akuntabilitas, Dinas Tenaga Kerja dan Transmigrasi Provinsi Riau melakukan apa yang seharusnya dilakukan, menurunkan tingkat pengangguran terbuka sesuai dengan visi dan misi Dinas Tenaga Kerja dan Transmigrasi Provinsi Riau dan perubahan kemandirian masyarakat transmigrasi juga sudah terlihat karena telah adanya masyarakat yang tidak dibina lagi atau masyarakat yang sudah mandiri.

Hal ini juga didukung oleh hasil wawancara dengan salah satu masyarakat transmigrasi yang masih dibina yang mana masyarakat mengatakan bahwa beliau merasakan kepuasan terhadap program dan bantuan yang telah diberikan oleh Dinas Tenaga Kerja dan Transmigrasi Provinsi Riau. Dengan kepuasan masyarakat dapat dikatakan bahwa Pemerintah Provinsi telah bertanggung jawab dan konsisten atas tugasnya untuk memenuhi kehendak masyarakat banyak. Dinas Tenaga Kerja dan Transmigrasi Provinsi Riau melakukan tanggungjawabnya dengan membuat laporan yang di sebut LKjIP (Laporan Kinerja Instansi Pemerintah), di laporan itu kita dapat lihat berapa persentase target sasaran dan berapa persentase programnya terealisasikan. Berikut adalah tabel yang menunjukkan akuntabilitas kinerja Dinas Tenaga Kerja dan Transmigrasi Provinsi Riau pada tahun 2017 dan tahun 2018.

Tabel 3. Capaian Kinerja Dinas Tenaga Kerja dan Transmigrasi Provinsi Riau

\begin{tabular}{|c|c|c|c|c|c|}
\hline $\begin{array}{l}\text { Sasaran } \\
\text { Strategis }\end{array}$ & $\begin{array}{l}\text { Indikator } \\
\text { Sasaran }\end{array}$ & Tahun & Target & Realisasi & Capaian \\
\hline \multirow{4}{*}{$\begin{array}{l}\text { Menurunkan } \\
\text { Tingkat } \\
\text { Pengangguran } \\
\text { Terbuka }\end{array}$} & \multirow{2}{*}{$\begin{array}{l}\text { Tingkat } \\
\text { Pengangguran } \\
\text { Terbuka/TPT } \\
(\%)\end{array}$} & 2017 & $7,53 \%$ & $6,22 \%$ & $121,06 \%$ \\
\hline & & 2018 & $6,68 \%$ & $6,20 \%$ & $107,74 \%$ \\
\hline & \multirow{2}{*}{$\begin{array}{l}\text { Tingkat } \\
\text { Partisipasi } \\
\text { Agkatan } \\
\text { Kerja/TPAK } \\
(\%) \\
\end{array}$} & 2017 & $63,52 \%$ & $64 \%$ & $100.76 \%$ \\
\hline & & 2018 & $63,67 \%$ & $65,23 \%$ & $102,45 \%$ \\
\hline \multirow{2}{*}{$\begin{array}{l}\text { Meningkatnya } \\
\text { kemandirian } \\
\text { warga } \\
\text { transmigrasi } \\
\end{array}$} & \multirow{2}{*}{$\begin{array}{l}\text { Persentase } \\
\text { Transmigrasi } \\
\text { Mandiri }\end{array}$} & 2017 & $24 \%$ & $23 \%$ & $95,83 \%$ \\
\hline & & 2018 & $45 \%$ & $35,61 \%$ & $79,14 \%$ \\
\hline
\end{tabular}

Sumber: Disnakertrans Provinsi Riau, 2018

\section{Hambatan Kinerja Organisasi Publik}

Dalam melakukan suatu pekerjaan atau menjalankan suatu program untuk mencapai target sasaran kinerja yang dilakukan oleh Dinas Tenaga Kerja dan Transmigrasi Provinsi Riau terdapat hambatan atau kendala yang ditemukan, sebagaimana ditemukan pada hasil dari penelitian ini disesuaikan dengan teori yang penulis gunakan diatas menurut Wibowo (2011), yaitu:

\section{Faktor kelompok}

Dalam faktor ini, hambatan yang dialami yaitu kurangnya kerja sama dengan masyarakat dalam pelaksanaan kegiatan pelatihan, kurangnya kerja sama dengan perusahaan yang berpartisipasi pada program Job Fair. Dalam kendala pelaksanaan kegiatan pelatihan, Dinas ini langsung turun ke daerah pelaksanaan pelatihan untuk mencari tambahan peserta lagi kemudian pada hari itu juga langsung dilaksanakan pelatihan yang akan dilaksanakan tadi.

Kendala selanjutnya itu kurangnya kerjasama antara instansi dan perusahaan-perusahaan, sehingga terjadilah minimnya jumlah perusahaan yang memenuhi kriteria untuk mengikuti program jobfair. Dinas ini melakukan pengunduran jadwal pelaksanaan job fair sampai jumlah perusahaan yang memenuhi persyaratan itu bisa ikut berpartisi sudah mencapai target, tetapi program job fair tetap terlaksana sesuai perjanjian yang ditentukan, yaitu satu kali setiap tahun.

\section{Faktor sistem}

Faktor ini berkaitan dengan sistem/metode kerja, fasilitas atau infrastruktur yang diberikan oleh organisasi. Pada faktor system, hambatan yang timbul, yaitu lokasi pelaksanaan pemagangan yang hanya menerima $30 \%$ dari jumlah karyawan perusahaan yang bersangkutan dan terbatasnya anggaran yang diterima pemerintah daerah dari pemerintah pusat.

Untuk mengatasi kendala pada faktor system ini, Dinas ini melakukan pemagangan yang hanya menerima $30 \%$ dari jumlah karyawan perusahaan yang bersangkutan, Dinas Tenaga Kerja dan Transmigrasi Provinsi Riau mencari perusahaan-perusahaan lagi yang mampu menerima siswa pemagangan agar target instansi ini 
tetap tercapai. Untuk kendala efisiensi anggaran, Dinas Tenaga Kerja dan Transmigrasi Provinsi Riau melakukan pengajuan anggaran dengan cara mengajukan RAPBD atau Rancangan Anggaran Pendapatan dan Belanja Daerah agar tercapai tujuan program-program yang direncanakan sebelumnya pada tahun selanjutnya dan sesuai dengan undang-undang yang telah ditetapkan.

\section{Faktor situasi}

Faktor ini berkaitan dengan tingginya tingkat tekanan dan perubahan lingkungan, baik lingkungan internal maupun eksternal. Pada faktor situasi ini, terdapat hambatan seperti kurang memadainya sarana dan prasarana seperti jalanan menuju ke daerah transmigrasi, serta air pada daerah pemukiman transmigrasi tersebut. Kemudian lingkungan tersebut juga kurang mendukung untuk meningkatkan kemandirian masyarakat transmigrasi. Untuk mengatasi hambatan ini, pemerintah membuatkan sumur bor atau minimal sumur galian agar masalah air di pemukiman transmigrasi itu tidak susah didapat, kalau kendalanya pada jalan itu Dinas Tenaga Kerja dan Transmigrasi Provinsi Riau meminta usulan untuk bekerja sama dengan Dinas Pekerjaan Umum agar Dinas Pekerjaan Umum memperbaiki jalanan darat menuju daerah tersebut minimal di keraskan saja.

\section{SIMPULAN}

Penilaian kinerja didasarkan pada indikator produktivitas, responsivitas dan akuntabilitas. Penilaian kinerja juga didasarkan pada sasaran kinerja Dinas Tenaga Kerja dan Transmigrasi Provinsi Riau. Dari hasil penelitian, dapat disimpulkan bahwa kinerja Dinas Tenaga Kerja dan Transmigrasi Provinsi Riau dikatakan baik. Dinas Tenaga Kerja dan Transmigrasi Provinsi Riau memberikan pelayanan seperti membuat program pelatihan wirausaha baru, pelatihan kader teknologi padat karya, dan program pemagangan, dengan ketiga program ini sasaran meningkatnya perluasan kesempatan kerja di sektor informal, meningkatnya kompetensi tenaga kerja, dan meningkatnya penyebarluasan informasi ketenagakerjaan kepada tenaga kerja, masyarakat, dan perusahaan dapat tercapai. Hal ini dapat dilihat dari banyaknya peserta yang mengikuti pelatihan serta pemagangan sehingga para peserta memiliki kompetensi, produktif dan berdaya saing tinggi sesuai dengan pasar kerja. Dinas ini juga melaksanakan program job fair untuk mencapai sasaran mengurangi angka pengangguran, tetapi dapat dilihat pada grafik dilatar belakang masalah bahwa angka pengangguran pada tahun 2017 ke tahun 2018 hanya menurun sedikit, dan ini terdapat seperti kurang maksimalnya program dijalankan.

Pada sasaran penyelesaian hubungan industrial dan meningkatnya pengawasan ketenagakerjaan, Dinas ini mampu menyelesaikan semua pengaduan yang diterima dari para tenaga kerja yang melakukan pengaduan dan dengan menjalankan program norma kerja, jaminan sosial, perempuan dan anak serta program Kesehatan dan Keselamatan Kerja (K3), Dinas Tenaga Kerja dan Transmigrasi Provinsi Riau mampu meningkatkan pengawasan para tenaga kerja untuk terus berhati-hati dalam bekerja. Kemudian, dinas ini meminta untuk setiap perusahaan mendaftarkan para karyawannya ke BPJS Ketenagakerjaan sebagai jaminan sosial yang diberikan dari instansi sehingga dengan program ini dapat mencapai sasaran meningkatnya kepesertaan jamsostek.

Untuk mencapai sasaran penempatan transmigrasi yang berkualitas dan kemandirian transmigrasi, Dinas ini memberikan bantuan, memberikan bibit-bibit tanaman, bibit-bibit ikan, membangunkan fasilitas, dan memberikan sosialisasi-sosialisasi mengenai peluang usaha dan penyuluhan mental spiritual. Dinas Tenaga Kerja dan Transmigrasi Provinsi Riau juga melakukan monitoring dan evaluasi pada waktu yang telah ditetapkan, bagaimana programnya berjalan, seberapa besar pengaruh dari program yang dilaksanakan, berapa banyak para pencari kerja yang diterima melalui program yang dilaksanakannya, bagaimana perkembangan masyarakat transmigrasi. Pada produktivitas kinerja ini, hanya saja terkendala pada kurang efisiennya anggaran biaya sehingga program yang dijalankan dan proses pembangunan fasilitas menjadi sedikit terhambat.

Dalam menanggapi tuntutan, keluhan atau 
pengaduan tenaga kerja dan masyarakat, Dinas ini berusaha untuk merespon dengan cepat sesuai dengan prosedur kerja dalam penyelesaian kasus pengaduan dan untuk keluhan masyarakat transmigrasi tentunya Dinas ini melakukan pertimbangan terlebih dahulu sebelum bertindak memenuhi keluhan dari masyarakat tersebut. Dengan adanya kepuasan masyarakat terhadap tugas yang dilaksanakan oleh Dinas Tenaga Kerja dan Transmigrasi Provinsi Riau dapat dikatakan bahwa Pemerintah Provinsi telah bertanggung jawab dan konsisten atas tugasnya untuk memenuhi kehendak masyarakat banyak.

\section{DAFTAR RUJUKAN}

Akbar Rusdi, 2012. Performance Measurement in Indonesia: The Case of Local Government, Pacific Accounting Review, 24 (3).

Baker, K. R., \& Trietsch, D. 2009. Principles of Sequencing and Scheduling. Canada: John Wiley \& Sons Inc.

Bastian, Indra. 2001. Akuntansi Sektor Publik di Indonesia. Yogyakarta: BPFE.

Dwiyanto, Agus. 2006. Reformasi Birokrasi Publik di Indonesia. Yogyakarta: PPSK-UGM.

Ella Wargadinata, 2017. Kualitas Pengukuran Kinerja Organisasi Publik, Jurnal
Sosiohumaniora, 19 (2)

Hanifah, Indri. 2018. Kinerja Dinas Tenaga Kerja dan Transmigrasi dalam Melaksanakan Program PenguranganAngka Pengangguran di Kota Bogor. Jurnal Governasi, 4 (1).

Mardiasmo. 2009. Akuntansi Sektor Publik. Yogyakarta: Andi.

Mihaiu Diana Marieta, Opreana Alin, Cristecu Marian,2010, Efficiency Efectiveness And Performance of The Public Sector, Romanian Journalof Economic Forecasting, 4 (2).

Nawawi Uha, Ismail. 2010. Budaya Organisasi Kepemimpinan \& Kinerja. Jakarta: Prenadamedia Group.

Pasolong, Harbani. 2010. Teori Administrasi Publik. Bandung: Alfabeta.

Sedarmayanti. 2007. Manajemen Sumber Daya Manusia. Bandung: RefikaAditama.

Simamora, Henry. 2004. Manajemen Sumber Daya Manusia. Yogyakarta: STIE YKPN.

Surjadi. 2009. Pengembangan Kinerja Pelayanan Publik. Bandung: Refika Aditama.

Wibowo. 2011. Manajemen Kinerja. Jakarta: Raja Grafindo Persada.

Zauhar, Soesilo. 2005. Birokrasi, Birokratisasi dan Post Bureaucracy. Malang: Unibraw. 